\title{
THE ROLE OF SUPERVISOR SUPPORT IN PREDICTING EMPLOYEE J OB SATISFACTION FROM THEIR PERCEPTION OF THE PERFORMANCE MANAGEMENT SYSTEM: A TEST OF COMPETING MODELS IN ENGINEERING ENVIRONMENTS
}

\author{
S. Baloyi ${ }^{1 *}$, C.C. van Waveren ${ }^{2} \&$ K. $-Y$. Chan $^{3 \dagger}$ \\ Department of Engineering and Technology Management \\ Graduate School of Technology Management \\ University of Pretoria, South Africa \\ ${ }^{1}$ simon. baloyi@sasol.com; ${ }^{2}$ corro@up.ac.za; ${ }^{3}$ alice.chan@up.ac.za
}

\begin{abstract}
Past studies of performance management systems (PMS) have focused more on designing the framework and less on the effect it has on employees. Moreover, employees in developing countries may not be knowledgeable or familiar with PMS. This paper proposes two competing statistical models to examine the roles that supervisor support (SS) has in engineering organisations. It was found that SS is a mediator, but not a moderator, in the relationship between PMS and employee job satisfaction. In other words, SS partially explains why employees have positive perceptions of their jobs based on their evaluation of the current PMS; SS thus enhances the PMS in engineering organisations.
\end{abstract}

\section{OPSOMMING}

Vorige studies van prestasiebestuurstelsels het op die ontwerp van die raamwerk, eerder as die effek daarvan op werknemers, gefokus. Verder is werknemers in ontwikkelende lande dikwels nie ingelig en vertroud met prestasiebestuurstelsels nie. Twee meedingende statistiese modelle om die rol van toesighouerondersteuning te ondersoek word voorgestel. Daar is gevind dat toesighouerondersteuning in die verhouding tussen prestasiebestuurstelsels en werksbevrediging ' $\mathrm{n}$ bemiddelaar eerder as ' $\mathrm{n}$ moderator is. Toesighouerondersteuning verduidelik dus hoekom werknemers positiewe persepsies van hulle werksgeleenthede koester, gegrond op hul evaluering van die huidige prestasiebestuurstelsel. Toesighouerondersteuning bevorder dus die prestasiebestuurstelsel in ingenieursfirmas.

\footnotetext{
* The author was enrolled for an MEng (Engineering Management) degree in the Graduate School of Technology Management, University of Pretoria

${ }^{\dagger}$ Corresponding author
} 


\section{$1 \quad$ INTRODUCTION}

Performance management is a holistic and integrated process concerned with individuals' performances in an organisation; it enables them to have a shared objective with the company, and to remain committed and motivated [1, 2]. The literature suggests that companies with an effective performance management system are likely to have highly motivated employees with a high level of job satisfaction [3, 4]. Although a satisfied employee is not necessary a good performer, a dissatisfied employee "can cause irreparable damage to the organisational effectiveness" [5].

Engineering organisations are involved in a technologically sophisticated environment where "the products and processes produced or utilized in the industry involve the use of very sophisticated and complex operations technologies" [6]. Human resource issues are important in technology-driven industries because it is the human resource that makes the technology productive [7]. Therefore, performance management systems (PMS), as part of human resources management, is considered in this study to be important in technologydriven firms to reduce uncertainties and risks that may arise when employees interact with these complex technologies. Moreover, it is suggested that performance management systems in technology-driven industries need to incorporate employee perspectives such as satisfaction and commitment [7]. Studies exploring the relationship between the PMS system and employees' perceptions were performed in organisations with less complex technologies, such as libraries [5] and the government [8]. These studies were performed mainly in developed countries. This study tries to close the gap in the PMS literature by investigating the engineering organisations in the petrochemical industry in South Africa, a representative of countries with an emerging economy. South Africa's chemicals sector (including the petrochemical industry, fine and specialty chemicals, polymers, and pharmaceuticals) is the country's largest manufacturing sector, accounting for some 5 per cent of gross domestic product (GDP) and about 25 per cent of its manufacturing sales [9]. This industry is the largest of its kind in Africa. It is highly complex and widely diversified, with end products often composed of a number of chemicals that have been combined in some way to provide the required properties and characteristics. In the context of the South African petrochemical industry, this paper aims to answer the following research questions:

1. Is there a relationship between a well-perceived performance management system (PMS) and employee perception?

2. What is the role of supervisors when organisations implement PMS?

By answering the above research questions, the objectives of the research study are to:

1. Establish whether there is a relationship between a performance management system and employee job satisfaction.

2. Determine the role of supervisor support that may impact on the relationship between the performance system and employee perception.

The contributions of this paper are twofold. First, this study adds to knowledge of the theory of performance management by testing this theory in a developing country. It is shown that only 5 per cent of studies have tried to test institutional theory empirically in developing countries [10]. De Wall [11] stated that performance management is one of the institutional theories "whose validity needs to be tested in an emerging country's context, as this context can be more dynamic and be completely different from a developed country's context". Moreover, it is found in the literature review that most studies on performance management and employee job satisfaction are performed in industries that have less complex technologies. This study proposes that engineering organisations face a technologically complex and fast-changing environment; social exchange relationships are thus extra important in PMS because supervisory support can enable subordinates to operate or develop these complex technologies. This paper takes the South African 
petrochemical industry as a case study, and contributes to the field of performance management from an emerging economy and engineering management perspective. Second, this paper proposes two functions that supervisors may play in the relationship between PMS and employee job satisfaction: mediator and moderator. In the literature, 'moderator' and 'mediator' are used interchangeably, causing confusion. This paper distinguishes between the two functions from a conceptual, statistical, and practical point of view.

The remainder of this paper is structured as follows: Section 2 provides several hypotheses based on the link between PMS and job satisfaction. Section 3 describes the research methodology that was followed and the data analysis techniques that were used to test the hypotheses. Section 4 describes the empirical results from the multivariate analysis; and the last section offers concluding remarks with recommendations for managerial practices and future research.

\section{THE CONCEPTUAL MODEL}

Employment relationships are considered to be central to performance management. One of the perspectives is the personal or human dimension (the psychological contract) [12]. This is in line with the traditional definition of performance management in which the individual employee is the focus of attention [13]. In this study, the psychological contracts of the employees are seen as their perceptions of job satisfaction [14]. Employees' perceptions of their job are generally expected to be positively influenced by most aspects of performance management, especially those that relate to the welfare and development of individuals [3]. J ob satisfaction has been defined in the literature as "a collection of attitudes about different aspects of the job and work context" [15]. A well-developed PMS includes individual objectives that are linked to the organisation's objectives [1]. If the employees are well-informed and understand their objectives within the organisation through the PMS, then they might find their work easier. Thus the first hypothesis reads:

Hypothesis 1: A well-perceived PMS increases employees' job satisfaction

Coaching behaviour was viewed as a master-apprentice type of relationship in the 1950s [16]. It was only in the 1980s and 1990s that such behaviour was explored in the managerial context - in particular, the relationship between supervisor support and job satisfaction. For example, Bateman and Organ [17] stated that “... a person's satisfaction results from the efforts of organizational officials". Supervisor support creates "enabling relationships with others that make it easier for them to learn" [18]. In line with this thought, supervisor support is considered to facilitate employees' learning and development [19]. From leadermember exchange (LMX) research, it is known that LMX is associated with the leader providing support and guidance to the member [20]. Moreover, Griffin and others [21] defined employee experiences of supervisor support as "the extent to which supervisors provide encouragement and support to employees within their work groups", and found a positive relationship between supervisor support and employee job satisfaction. In the context of this study, it is postulated that the work context in a technology-driven environment is complex, and support needs to be given for the employee to interact with these complex technologies. Without support from supervisors, employees may feel stressful at work [22], and as a result may feel dissatisfied with their jobs [23]. From this argument the second hypothesis is formulated:

\section{Hypothesis 2: Supervisor support increases employees' job satisfaction}

A company can have a sophisticated PMS; but it needs to be supported by the line managers (supervisors) who put PMS into practice [12]. Employees may not necessarily understand all the aspects of the PMS that the company develops or brings in. This is especially valid for employees in developing countries, who are generally not as well-educated as those in developed countries. Thus support from supervisors may be important to helping employees to understand the content of PMS fully. Supervisor support may therefore act as a mediator 
in the relationship between the PMS and employee job satisfaction. The terms 'mediator' and 'moderator' have, however, been used interchangeably, and thus may cause some confusion [24]. Many studies in the field of social psychology have tried to distinguish between these two functions [24, 25, 26]. Moreover, the mediating and moderating effects of supervisor support are competing (i.e. mutually exclusive) models: they represent multiple theoretical formulations that can be constructed when interfacing two distinct bodies of literature, such as PMS and job satisfaction. Theoretically, a moderator affects the direction or strength of the relation between an independent (or a predictor) variable and a dependent variable, whereas a mediator accounts (to an extent) for the relationship between the predictor and the dependent variable. In other words, questions involving moderators address when or for whom a variable most strongly predicts or causes an outcome variable; whereas mediators establish how or why one variable predicts or causes an outcome variable [26]. The difference between the two functions can be seen in Figure 1.

A. Direct Effects

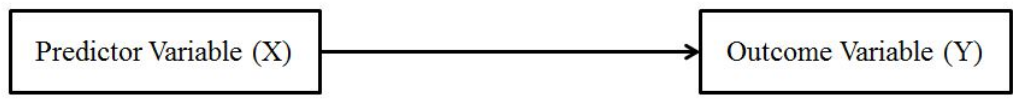

B. Moderator Effects

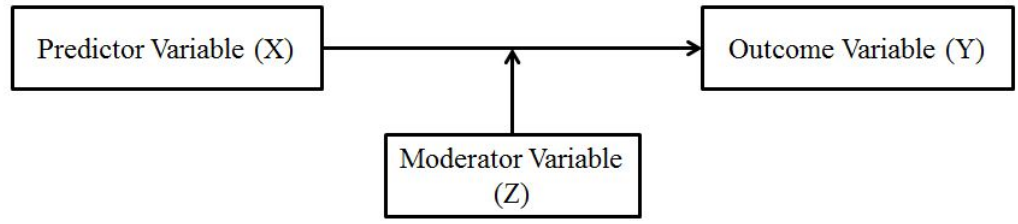

C. Mediator Effects

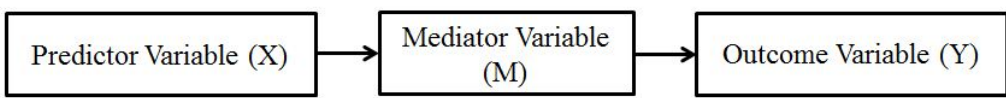

Figure 1: Diagrams of direct, moderator, and mediator effects

In order to clarify the function of supervisor support (whether as moderator or mediator), two additional hypotheses are formulated:

Hypothesis 3: Supervisor support mediates the direct effect of PMS on employees' job satisfaction

Hypothesis 4: Supervisor support moderates the direct effects of PMS on employees' job satisfaction

The theoretical framework for the first two hypotheses is summarised in Figure 2. The theoretical framework for Hypothesis 3 and Hypothesis 4, for examining supervisor support as mediator and moderator, is shown in Figure 3.

\section{RESEARCH METHODOLOGY}

In the first stage of data collection, the researcher conducted preliminary interviews to collect qualitative data on the subject from ten randomly selected employees in the petrochemical industry. These preliminary interviews were used as an additional data gathering technique to design and refine the main questionnaire, and especially to clarify the questions being asked. 


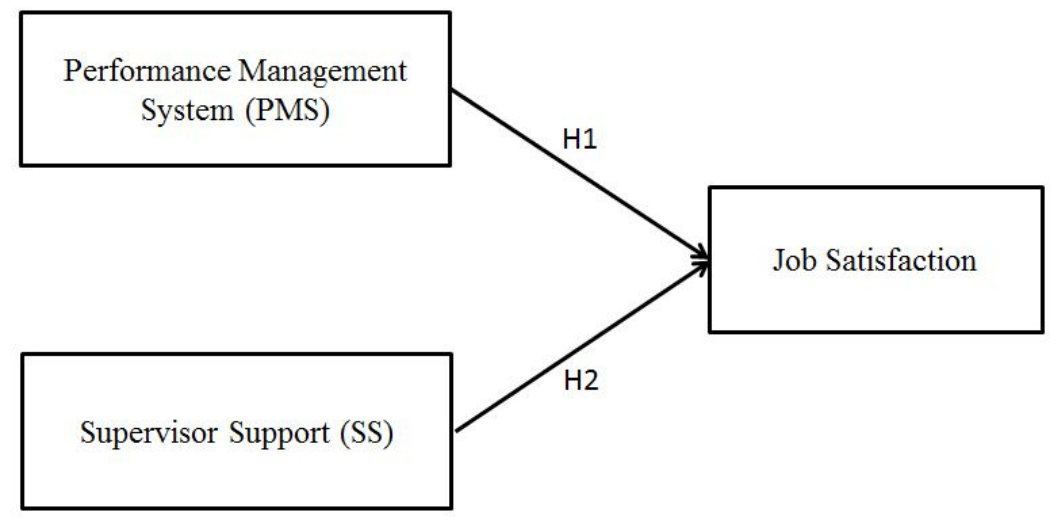

Figure 2: Main effects of a performance management system and of supervisor support (Hypotheses 1 and 2).

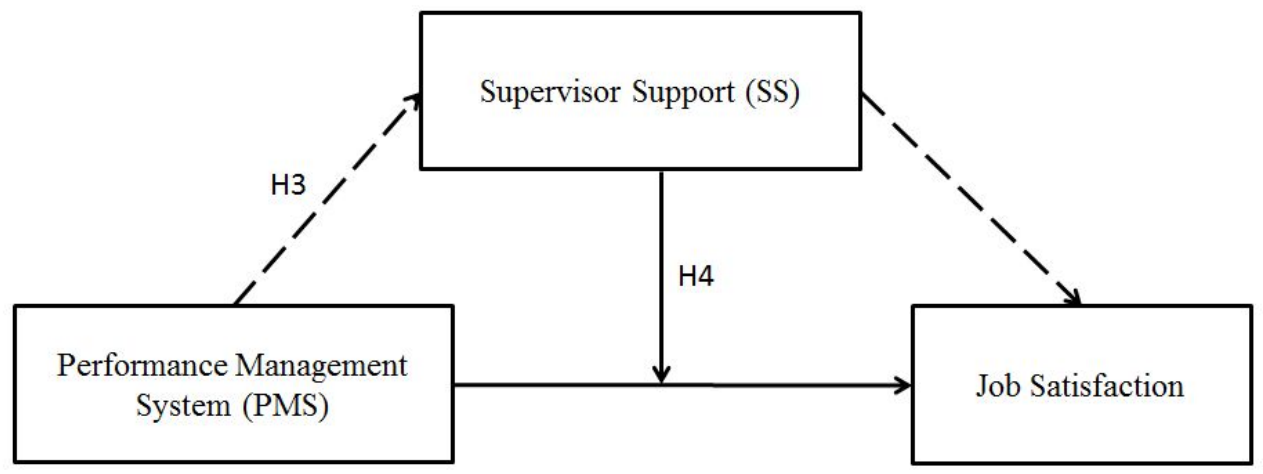

Figure 3: Mediating and moderating effects of supervisor support in a performance management system. The mediated effect of supervisor support is indicated by dashed lines (Hypothesis 3). The moderated effect of supervisor support is indicated by solid lines (Hypothesis 4).

In the second stage, the main questionnaire was designed using the constructs gathered from the preliminary interviews as well as themes highlighted in the literature review. The questionnaires were distributed to employees of petrochemical companies in the Gauteng Province - the economic hub of South Africa.

The target population was employees of petrochemical organisations headquartered in the Gauteng area. The companies that were surveyed were chosen from a list in the Mbendi database (http:/ / www. mbendi. com/ indy/ chem/ prtc/ af/ sa/ p0005. htm\#Companies)

The survey received 148 responses from members of different companies in the petrochemical industry. Of the 148 surveys, 138 were correctly completed; thus 93.2 per cent of the total collected surveys were usable for this research.

A theoretical framework was established in the previous section, aiming to answer research questions. Table 1 illustrates the items that were used in the questionnaire to measure the variables proposed in the framework. A five-point Likert scale was used to assess each item. 
Table 1: Variables and measurements

\begin{tabular}{|c|c|}
\hline Independent variables & Item(s) \\
\hline $\begin{array}{l}\text { Performance } \\
\text { management } \\
\text { (PMS) }\end{array}$ & $\begin{array}{l}\text { Indicate level of agreement with the following statements: } \\
\text { (1) The performance management system in my company is fair. } \\
\text { (2) The performance management system in my company is } \\
\text { implemented continuously not just a once off event. } \\
\text { (3) My company's performance system has clear objectives and } \\
\text { measures actual output rather than perceptions. } \\
\text { (4) The performance management system allows my company to } \\
\text { clearly communicate key performance strategies and goals } \\
\text { across the entire organisation. } \\
\text { (5) My company's performance management system allows } \\
\text { teamwork and collaboration among all key stakeholders. } \\
\text { (5 points Likert scale: } 1 \text { = strongly disagree, } 3=\text { neither agree nor } \\
\text { disagree, } \\
5=\text { strongly agree) }\end{array}$ \\
\hline Supervisor support & $\begin{array}{l}\text { Indicate level of agreement with the following statements: } \\
\text { (1) My immediate supervisor trusts me. } \\
\text { (2) My immediate supervisor helps me to improve myself. } \\
\text { (3) My immediate supervisor takes prompt and fair corrective action } \\
\text { on employees who fail to perform their work satisfactorily. } \\
\text { (4) My immediate supervisor establishes plans and work objectives } \\
\text { with me. } \\
\text { (5) My immediate supervisor gives me clear instructions. } \\
\text { (6) My immediate supervisor is available when I need advice. } \\
\text { (7) I feel free to talk openly and honestly to my manager. } \\
\text { (8) My immediate supervisor praises me when I do a good job. } \\
\text { (9) My immediate supervisor holds regular meetings with my work } \\
\text { (10) My immediate supervisor is effective in making decisions. } \\
\text { (11) My immediate supervisor knows what is going on in my work } \\
\text { (12) My immediate supervisor is doing a good job. } \\
\text { (5 points Likert scale: } 1 \text { = strongly disagree, } 3=\text { neither agree nor } \\
\text { disagree, } \\
5 \text { = strongly agree) }\end{array}$ \\
\hline Dependent variables & Item(s) \\
\hline J ob satisfaction & $\begin{array}{l}\text { Indicate level of agreement with the following statement: } \\
\text { (1) I am satisfied with my job and the kind of work I do. } \\
\text { (2) I am satisfied with my working conditions. } \\
\text { (3) Overall, I am satisfied with my present job. } \\
\text { (4) I am satisfied with the job opportunities in the company. } \\
\text { (5) I am satisfied with the opportunities for training. } \\
\text { (5 points Likert scale: } 1 \text { = strongly disagree, } 3 \text { = neither agree nor } \\
\text { disagree, } \\
5 \text { = strongly agree) }\end{array}$ \\
\hline
\end{tabular}

\section{EMPIRICAL RESULTS}

The result of the descriptive analysis for the variables proposed in the theoretical framework to answer the research question is discussed below. In order to test the construct validity of the questionnaire, the items under each variable were entered in a principal component factor analysis that produces a one-factor solution (see Table 2). The Kaiser-Meyer-Olkin (KMO) indicators, as shown in the table, are all greater than 0.75 . This value indicates that the application of the factor analysis is appropriate. Cronbach's alpha is used to measure the reliability of a set of questions in a survey instrument. Cronbach's 
alpha of 0.7 was used as a threshold value, suggesting that a variable can thus be measured with a single, uni-dimensional latent construct. The results in Table 2 show that all the Cronbach's alpha values are greater than 0.7 (with significant Bartlett's Test of Sphericity at $p \varangle 001$ ), indicating that the questionnaire is reliable. The score for each variable is represented by taking the average score of all the items associated with the variable.

Table 2: KMO, Cronbach's alpha, means, and standard deviations of variables

\begin{tabular}{|l|c|c|c|c|}
\hline Variables & KMO & Cronbach's a & Mean & Std. dev. \\
\hline $\begin{array}{l}\text { Performance management } \\
\text { system (PMS) }\end{array}$ & 0.807 & 0.791 & 3.326 & 0.809 \\
\hline Supervisor support (SS) & 0.949 & 0.959 & 3.5882 & 0.91944 \\
\hline J ob satisfaction & 0.766 & 0.835 & 3.5843 & 0.75786 \\
\hline
\end{tabular}

Means and standard deviations of the variables under study are presented in Table 2.

In addition to the descriptive analysis, a multivariate analysis was performed to test the hypotheses proposed in the theoretical framework. The models in this study were estimated, using Statistical Package for the Social Sciences (SPSS) to perform ordinary least square (OLS) hierarchical regression analyses. The independent variables were entered in three steps:

Model 1: PMS variable only

Model 2: Model $1+$ SS

Model 3: Model $2+$ PMS*SS

The results of the regression models above are shown in Table 3.

Table 3: OLS regression results

\begin{tabular}{|l|c|c|c|}
\hline \multirow{2}{*}{} & \multicolumn{3}{|c|}{ Dependent variables: J ob satisfaction } \\
\cline { 2 - 4 } & Model 1 & Model 2 & Model 3 \\
\hline Constant & $3.609^{*}$ & $3.615^{*}$ & $3.643^{*}$ \\
Independent variables: & & & \\
PMS & $0.589^{*}$ & $0.330^{*}$ & $0.316^{*}$ \\
SS & & $0.457^{*}$ & $0.444^{*}$ \\
PMS*SS & & & -0.073 \\
\hline R-square & $34.7 \%$ & $48.9 \%$ & $49.4 \%$ \\
Change of R-square & $34.7 \%$ & $14.2 \%$ & $0.5 \%$ \\
F-value & $58.502^{*}$ & $52.169^{*}$ & $35.114^{*}$ \\
Change of F-value & $58.502^{*}$ & $30.270^{*}$ & 1.002 \\
VIF & 1.000 & 1.473 & $1.123-1.513$ \\
\hline
\end{tabular}

The variables are mean-centred to avoid multicollinearity, which often causes problems in

least squares regression [27]. The two predictors, PMS and SS, are shown in the table to have positive and significant impacts on job satisfaction in all three models. Thus Hypotheses 1 and 2 are fully supported.

In order to test Hypothesis 3, with SS as a mediator, the following criteria should be met:

1. Is there an association of the predictor (PMS) with the mediator (SS)?

2. Is there an association of the mediator (SS) with the dependent variable (job satisfaction)? 
3. Is there an association of the independent variable (PMS) with the dependent variable (j ob satisfaction)?

4. Does the association of the independent and dependent variables reduce significantly (partial mediation) or disappear (full mediation) when the mediator is added?

The first criterion above was tested by analysing an additional regression model, where PMS was the independent variable and SS was the dependent variable. The beta value for this model was 0.574 (significance of beta value is $p \varangle 0.01 ; R^{2}=32.9 \%$ F-value $=55.014$, significant at $p \varangle 0.01$ ). This result shows that there is a positive association of the predictor (PMS) with the mediator (SS). Thus Criterion 1 is met. For Criteria 2 and 3, one can see from both Model 1 and Model 2 in Table 3 that PMS and SS each have a positive association with the respective dependent variables. To examine Criterion 4, one can see the change in the model from Model 1 to Model 2. In Model 1, the PMS value was entered to examine its impact on the dependent variable. The beta value of PMS decreased when SS was entered in Model 2. This result shows that the association of the independent variable (PMS) and of the dependent variable ( $\mathrm{job}$ satisfaction) reduced when the mediator (SS) was added. Thus Criterion 4 is met. This means that SS plays the role of a mediator, and Hypothesis 3 is supported.

An additional term is added in Model 3 to test Hypothesis 4 (with SS as a moderator). This term is the product of PMS and SS. By adding this term into the model, one can see whether or not the interaction effect takes place. From Model 3 in Table 3, one can see that the product term does not have a significant impact on the dependent variable. In other words, SS does not influence the relationship between PMS and the dependent variable. Thus SS does not act as a moderator, and Hypothesis 4 is rejected.

\section{DISCUSSION AND CONCLUSION}

Performance management systems are important tools for aligning individuals' performances to their organisational objectives. Employees who have a shared objective are more committed to the organisation, and perceive their jobs and company at a higher level. This study proposes PMS as an important human resource management tool in engineering organisations. These firms operate in a technology-driven environment where employees work with complex technologies. Previous studies on the issues of PMS have focused mainly on developed countries and non-engineering industries. This study tries to contribute to the field of PMS by exploring the key factors to be considered by engineering organisations (in this case, the petrochemical industry in South Africa) when developing a performance management system. This study explores the inter-relationships between the performance management system and employee job satisfaction, and especially the role played by supervisor support in these relationships.

The research question explores the relationship between a well-implemented performance management system and employee perception. In addition, this study argues that supervisors play an important role in implementing a PMS. The function of supervisor support (SS) can be a mediator and/ or a moderator in the relationship between a PMS and employee perception. In the case of a mediator, SS explains how or why a PMS predicts or causes employee perception. If SS is a moderator, it addresses when a PMS most strongly predicts or causes employee perception. Four main hypotheses were formulated to address the two main effects of PMS and SS on employee perception, and the mediating and moderating effect of SS on the relationship between a PMS and employee perception. To test for internal consistency (how well the items that make up an instrument fit together), reliability and factor analysis were performed, and showed positive results (Cronbach's alpha greater than 0.7; one factor for each variable was found). To test the hypotheses, ordinary least square (OLS) hierarchical regression analyses were performed using the SPSS software package. The results supported the first three hypotheses and rejected the last one. In other words: 
- A well-perceived performance management system causes positive employee perception of their jobs.

- $\quad$ Support from supervisors causes positive employee perception of their jobs.

- Supervisor support acts as a mediator in the relationship between the performance management system and job satisfaction.

- Supervisor support does not act as a moderator in the relationship between the performance management system and job satisfaction.

When supervisor support is a mediator, it provides an explanation of why employees have a positive perception about their jobs, based on their evaluation of the PMS. From attribution theory $[28,29]$, it can be explained that when an employee (a target person) experiences a certain scenario, he/ she is very likely to attribute the experience to his/her leader. If employees perceive the performance management system poorly, they will associate this experience with their line managers or supervisors and blame them for poor support. This leads to job dissatisfaction in the employees. By contrast, if the employees perceive a good PMS, they will attribute this experience to good support from the supervisor, and feel satisfied about their job. The finding in this study is in line with the finding from Den Hartog and others [12], who proposed that front-line managers play a crucial mediating role when implementing these practices of performance management. Supervisors need to be consistent and fair when using performance management tasks such as "holding consultation meetings and conducting appraisal interviews" [12]. Supervisors not only give feedback about the subordinate's performance, they should also "provide encouragement, information about expectations that they and others hold for the individual, demonstrates of how to do things well, opportunities to practice new behaviours and receive feedback in a nonthreatening environment, and praise for success along the way to performance improvement" [30]. These activities supported by the supervisors have intervening effects on employees' perceived PMS and job satisfaction.

The competing model, in which supervisor support is proposed as moderator, was not supported in this study. Previous studies recognise social exchange as a buffer or an intensifier [31]. In other words, if employees perceive the PMS to be poor, but have a positive social exchange with their supervisor (for example, they have high perceived supervisor support), they might not necessarily feel dissatisfied about their jobs. On the other hand, if the perceived PMS is poor and the social exchange is low (the employees have low perceived supervisor support), the feeling of job dissatisfaction will intensify. As mentioned earlier, this competing model was not supported in this study, which means that the perceived supervisor support has no impact on the direct relationship between PMS and job satisfaction. This study recommends that engineering organisations should not only design and implement an effective PMS in the organisation, but also that they should create a positive supervisor supporting environment for subordinates. This is because, in the case of high perceived supervisor support, subordinates are willing to remain satisfied with their job regardless of how they perceive the PMS; whereas, with low perceived supervisor support, the perceived PMS will be critical to the subordinates' job satisfaction level. Moreover, it has been shown in previous studies that when employees perceive high support in the work environment, they exhibit effective commitment to the organisation, with a positive feeling of 'pay back' towards the organisation [32]. The level of employees' organisational commitment also impacts positively on employees' psychological rewards, such as job satisfaction [33].

\section{RESEARCH LIMITATIONS AND SUGGESTIONS}

Even though these findings provide valuable insights, this study has some limitations. First, the sample consists of 138 respondents who were randomly selected from major petrochemical companies headquartered in Gauteng, South Africa; and this could raise generalisation concerns. Similar studies could be performed in other technology-driven industries of South Africa so that the results are more generalisable in the context of South Africa and comparable emerging economies. Second, it is found in this study that supervisor support acts as a partial mediator in the relationship between the PMS and employee 
perception. This means that SS is not the only reason that employees feel satisfied with their jobs and their company, based on their positive evaluation of the implemented PMS. There may be other causes, such as political or social image [7], that can be added into the theoretical framework for further investigation.

\section{REFERENCES}

[1] Dransfield, R. 2000. Human resource management. Oxford: Heinemann Educational Publishers.

[2] Armstrong, M. \& Baron, A. 2005. Managing performance: Performance management in action. London: CIPD.

[3] Fletcher, C. \& Williams, R. 1996. Performance management, job satisfaction and organizational commitment, British J ournal of Management, 7(2), pp 169-179.

[4] Harper, S. \& Vilkinas, T. 2005. Determining the impact of an organisation's performance management system, Asia Pacific J ournal of Human Resources, 43(1), pp 76-97.

[5] Mallaiah, T.Y. 2008. Performance management and job satisfaction of university library professionals in Karnataka: A study, J ournal of Library Information and Technology, 28(6), pp 3944.

[6] Khandwalla, P.N. 1976/1977. Some top management styles, their context and performance, Organization and Administrative Science, 7(4), pp 21-51.

[7] Sureshchandar G.S. \& Leisten, R. 2005. Holistic scorecard: Strategic performance measurement and management in the software industry, Measuring Business Excellence, 9(2), pp 12-29.

[8] Taylor, P.J. \& Pierce, J.L. 1999. Effects of introducing a performance management system on employees' subsequent attitudes and effort, Public Personnel Management, 28(3), pp 423-453.

[9] DEAT (Department of Environmental Affairs and Tourism). South African National Profile 20022005. Pretoria: Chemical and Hazardous Waste Management.

[10] Farashahi, M., Hafso, T. \& Molz, R. 2005. Institutionalized norms of conducting research and social realities: A research synthesis of empirical works from 1983 to 2002, International J ournal of Management Review, 7(1), pp 1-24.

[11] De Wall, A. 2007. Is performance management applicable in developing countries? The case of a Tanzanian college, International J ournal of Emerging Markets, 2(1), pp 69-83.

[12] Den Hartog, D.N., Boselie, P. \& Paauwe, J. 2004. Performance management: A model and research agenda, Applied Psychology - An International Review, 53(4), pp 556-569.

[13] Smith P.C. \& Goddard, M. 2002. Performance management and operational research: A marriage made in heaven, J ournal of the Operational Research Society, 53(3), pp 247-255.

[14] Kutzscher, L.I., Sabiston, J.A., Laschinger, H.K. \& Nish, M. 1997. The effects of teamwork on staff perception of empowerment and job satisfaction, Healthcare Management Forum, 10(2), pp 12-24.

[15] McShane S.L. \& Steen, S. 2009. Canadian organizational behaviour. $7^{\text {th }}$ edition. Toronto: McGraw-Hill.

[16] Evered R.D. \& Selman, J.C. 1989. Coaching and the art of management, Organizational Dynamics, 18(2), pp 16-32.

[17] Bateman T.S. \& Organ, D.W. 1983. J ob satisfaction and the good soldier: The relationship between affect and employee citizenship, Academy of Management J ournal, 26(4), pp 587-595.

[18] Mink, O.G., Owen, K.Q. \& Mink, B.P. 1993. Developing high-performance people: The art of coaching. MA: Addison-Wesley.

[19] Ellinger, A.D., Ellinger, A.E. \& Keller, S.B. 2003. Supervisory coaching behaviour, employee satisfaction, and warehouse employee performance: A dyadic perspective in the distribution industry, Human Resource Development Quarterly, 14(4), pp 435-458.

[20] Wayne, S.J., Shore, L.M. \& Liden, R.C. 1997. Perceived organizational support and leadermember exchange: A social exchange perspective, Academy of Management Journal, 40(1), pp 82-111.

[21] Griffin, M.A., Patterson, M.G. \& West, M.A. 2001. J ob satisfaction and teamwork: The role of supervisor support, J ournal of Organizational Behavior, 22(5), pp 537-550.

[22] Lait J.\& Wallace, J.E. 2002. Stress at work: A study of organizational-professional conflict and unmet expectations, Industrial Relations, 57(3), pp 463-490.

[23] Ismail, A., Yao, A. \& Yunus, N.K.Y. 2009. Relationship between occupational stress and job satisfaction: An empirical study in Malaysia, The Romanian Economic J ournal, 34(4), pp 3-29.

[24] Baron R.M. \& Kenny, D.A. 1986. The moderator-mediator variable distinction in social psychological research: Conceptual, strategic, and statistical considerations, Journal of Personality and Social Psychology, 51(6), pp 1173-1182.

[25] Connor-Smith J.K. \& Compas, B.E. 2002. Vulnerability to social stress: Coping as a mediator or moderator of sociotropy and symptoms of anxiety and depression, Cognitive Therapy and Research, 26(1), pp 39-55.

[26] Frazier, P.A., Tix, A.P. \& Barron, K.E. 2004. Testing moderator and mediator effects in counselling psychology, J ournal of Counselling Psychology, 51(1), pp 115-134. 
[27] Kromrey J.D. \& Foster-J ohnson, L. 1998. Mean centering in moderated multiple regression: Much ado about nothing, Educational and Psychological Measurement, 58(1), pp 42-67.

[28] Calder, B.J. 1974. Information cues and attributions based on role behaviour, Journal of Experimental Social Psychology, 10(2), pp 121-125.

[29] Martinko, M.J., Harvey P. \& Douglas, S.C. 2007. The role, function, and contribution of attribution theory to leadership: A review, The Leadership Quarterly, 18(6), pp 561-585.

[30] London M. \& Smither, J.M. 2002. Feedback orientation, feedback culture, and the longitudinal performance management process, Human Resource Management Review, 12(1), pp 81-100.

[31] Bal, P.M., Chiaburu, D.S. \& Jansen, P.G.W. 2010. Psychological contract breach and work performance: Is social exchange a buffer or an intensifier? Journal of Managerial Psychology, 25(3), pp 252-273.

[32] Wayne S.J. \& Green, S.A. 1993. The effects of leader-member exchange on employee citizenship and impression management behaviour, Human Relations, 43(12), pp 1431-1441.

[33] Mathieu J. \& Zajac, D. 1990. A review and meta-analysis of the antecedents, correlates and consequences of organizational commitment, Psychological Bulletin, 108(2), pp 171-194. 